\title{
Identification of Landmarks in the Historic District of Banda Hilir, Melaka, Malaysia
}

\author{
Khairul Amin Mirsa Hussain, Norsidah Ujang \\ Department of Landscape Architecture, Faculty of Design and Architecture, \\ Universiti Putra Malaysia, 43400 Serdang, Selangor, Malaysia \\ khairul_amin3206@yahoo.com
}

\begin{abstract}
Landmark is one of the key elements that shape the image and identity of historic cities. It is evident that new and unfit developments have diluted the dominance of landmarks in Banda Hilir, Melaka. This paper examines visitors' identification of landmarks in the historic district of the city and its influence on their imageability. The study adopted mental mapping technique to gather images regarded as landmarks and its corresponding characteristics. Results from the study indicate that visitors identified both buildings and open spaces as landmarks. Size, façade, colour and scale of buildings and structures influence their identifications. This study denotes the importance of landmarks in preserving the image and identity of Banda Hilir as a world heritage site, despite the addition of new structures.
\end{abstract}

Keywords: landmark; historic city, imageability, place identity, Banda Hilir

eISSN 2398-4279 @ 2018. The Authors. Published for AMER ABRA cE-Bs by e-International Publishing House, Ltd., UK. This is an open access article under the CC BY-NC-ND license (http://creativecommons.org/licenses/bync-nd/4.0/). Peer-review under responsibility of AMER (Association of Malaysian Environment-Behaviour Researchers), ABRA (Association of Behavioural Researchers on Asians) and cE-Bs (Centre for EnvironmentBehaviour Studies), Faculty of Architecture, Planning \& Surveying, Universiti Teknologi MARA, Malaysia.

DOI: https://doi.org/10.21834/ajqol.v3i9.81 


\subsection{Introduction}

The existence of a city with good urban design qualities is necessary for a city to flourish. This is particularly relevant to a historic city in the striving for the preservation of its identity. Conservation and redevelopment continue to shape historic cities in the developing world. In the case of Malaysia, Melaka is the only city that has the longest urbanization history (Shuhana et. al, 2002). The city's landmarks have always been popular among visitors because of its historical values. These landmarks have also been regarded as elements of reference. Banda Hilir houses significant attraction such as A Famosa, Port de Santiago, St. Paul Church, St. Xavier Church, St. Paul Hill and Stadhuys. Most of these landmarks existed ever since the colonial era. Recent landmark features such as Dataran Pahlawan Melaka Megamall, Mahkota Parade, Muzium Samudera and Menara Taming Sari are some of the new additions in the city. Inscribed as World Heritage City since 2008 (Wan Hashimah, 2012), this city increases its attraction as a tourism site.

However, the historic district of Banda Hilir, Melaka faces a threat from the new development that diminishes the city's historical identity. Unfit physical changes dilute the identity of several of its distinctive elements regarded as landmarks. Despite the need to ensure contextual compatibility between old and new landmarks, most of the newer developments are focusing on commercial uses, which contradict with the established image and identity of the district. The absence of integration of design particularly between the development of modern and old buildings are crippling the identity of this historic area (Noorfadhilah and Shamzani, 2013). In this case heritage sites had to undergo a great pressure towards protecting the listed world heritage sites especially in urban site (Zalina and Rodzyah, 2012).

This paper discusses visitors' identification of landmark in Banda Hilir, Melaka. It is also to highlight the attributes and characteristics of the landmarks that influence the recognition. The findings will signify the effects of landmarks on visitors' experience of the city and elements that shape the original identity of the historic city.

\subsection{Litreature Review}

In the Image of the City, Lynch (1960) introduced the term "landmark" and its concept. According to him, landmarks are elements in a vertical form that are visible from far by an observer and function as a guide in wayfinding. In contrast with Lynch (1960), Hasanudin (2003) defines a landmark as any urban landscape feature that is different from its contextual characteristics, with manifested or inherent attributes. It is also physically or spiritually unique, influential and impressive.

. This shows that a landmark must not necessarily be a vertical or three-dimensional object. Hasanudin (2003) has categorized landmarks into four groups, namely natural landmarks, constructed landmarks, distant landmarks and local landmarks (Lynch, 1960). In this regards, he includes constructed open-spaces as an additional category of landmark. In this study, landmarks referred to as the visible and recognizable elements, either from far or in a space within in an area or a place, as long as they are distinctive from their surroundings 
while their spatial locations are remarkable Place identity refers to the individual's personal emotion and feeling in relationship to the environment and its distinctive characteristics features which developed the human-place bonding (Norsidah, 2010). Hence, it is important to understand the visitors' imageability based on the significant urban elements that make up the city image and identity. This is particularly relevant to historic cities, which are under the threat of place declining and placelessness due to the new development (Lai et. al., 2013). Identification of a landmark and recognition of its attributes and characteristic influence an individual's thoughts. These characteristics contribute to the attractiveness of the landmarks, which may influence visitors' imageability and memory of the city. Each landmark portrays either one or more of attributes which include scale, proportion and size, colours, singularity/ uniqueness/ different/ contrasting, location/ strategic position, ornamentation/ detail richness/ decoration, orientation/ wayfinding/ point of reference, symbolism and architectural values.

Every human creates his own mental image constructed from direct experiences. The images depended on personal appreciation, values and lifestyles (Sulsters, 2005). Mental maps assist for orientation and become more complex when a person gained much deeper understanding towards the area. The study used mental mapping technique to capture the visitors' mental images with regards to places they experience.

\subsection{Methodology}

The results from mental mapping and field observation techniques indicate the visitors' identification of landmarks. 35 respondents participated in the process based on the nonprobability or purposive sampling among the visitors of Banda Hilir, Melaka. Employing a qualitative research approach allowed the researcher to understand how people interpret their own experiences, a phenomenon's meaning that involves among them, and what meaning they bring to their experiences. Non-probability sampling or purposive sampling is the method of sampling that relevant to this study as claimed to be significant for most qualitative study. Furthermore, to ensure their confidentiality, all of the respondents are labelled for example R1which prefixes the first respondent in the interview session.

Mental maps represent what we know and remember about a place (Shuhana et. al., 2002). The invisible information could be gained from a simple or in-depth interview while or after the respondents draw their map.

During the mental mapping exercises, the researcher requested the visitors to draw a map that consist elements recognized as landmarks in Banda Hilir. In addition, respondents needed to sketch $2 \mathrm{D}$ or $3 \mathrm{D}$ drawings of elements they perceived as the most familiar landmark in the district of Banda Hilir. Later, an explanation from the respondents about their drawings or elements they sketched or written notes. The following highlights the instructions given to them:

i) Please draw a map of landmark (map that consist of the element that you recognized as landmarks) in Banda Hilir, Melaka on the given papers. State and identify the names of the landmarks sketched. (First stage of mental mapping)

ii) Next, please draw 2D or 3D view of the landmarks (you can draw more than one) that most familiar to you and show its specialties or characteristics (attributes) that make you 
recognized them (that make you attracted to them) in your drawing. (You can just write it if you could not draw the attributes or characteristic). (Second stage of mental mapping)

iii) State or explain your reasons for choosing the landmark and why it attracts your attention (i.e. Characteristics, attributes, meanings, attachment) (if any).

During the field observation, the researcher captured photographs to document the actual scene of the area. To form the findings of the research, researcher compared the mental mapping and field observation data and analyzed them descriptively.

\subsection{Findings and Discussions}

Banda Hilir has been demarcated by two main parts which are the core zone and the buffer zone. Core zone is the main area which consists of the heritage and historical places. This includes the area of the A. Famosa, St. Paul Church, St. Paul Hills, Bangunan Memorial Kemerdekaan and Red Square. However, there were also historical features which a bit far for a walking distance from the centre of the historical sites such as the St. Francis Xavier Church, Masjid Kg. Keling and Chee Mansion. This has caused the visitors not to be aware of its existence and therefore unable to identify the elements as landmarks. Visitors are mainly familiar with the centre of the core zone or the centre of the historic sites.

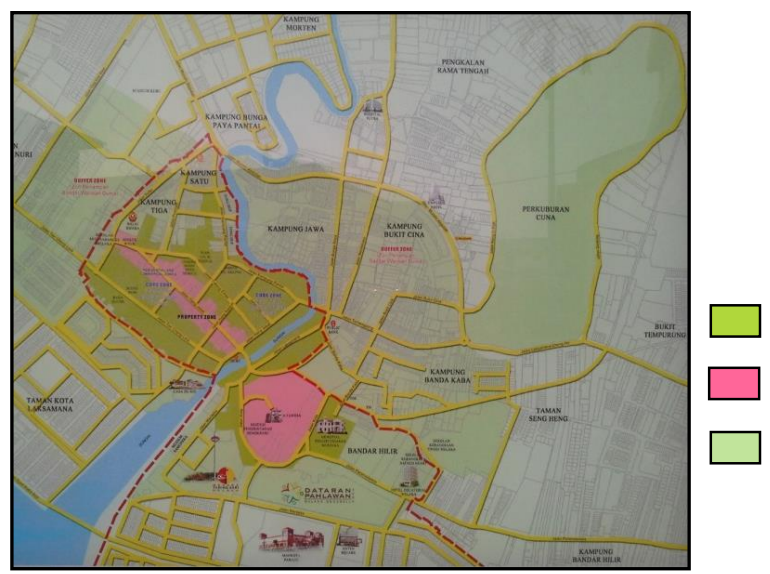

Core zone

Centre of the Core zone/ Historical site

Buffer Zone

Figure 1. Map showing core zone and the centre of the historical sites area in the city which consist the historical elements in Banda Hilir, Melaka. (Source: Majlis Bandaraya Melaka Bersejarah, 2013)

Meanwhile, the buffer zone consists of the residential area and some of the newly built elements at the city centre. This includes Menara Taming Sari, Muzium Samudera, Dataran Pahlawan Melaka Megamall, Mahkota Parade and also Casa Del Rio area. Although this area is the buffer zone, the image of the area has adversely affected the identity of the core zone since the two areas are still visually connected. Furthermore, one of the most significant 
features in Banda Hilir, the Dataran Pahlawan (previously known as Padang Pahlawan) is located in the buffer zone although it has high historical values. Padang Pahlawan should be a potential open space landmark for visitors, but it hardly functions as a local landmark for the area. It is can hardly be seen by the visitors due to its location as it is located above the ground floor of the Dataran Pahlawan Melaka Megamall. This scenario was described by some of visitors from the interview during the pilot study. As a result, none of the visitors recognized this square as a landmark in this study. They are more likely to identify Dataran Pahlawan Melaka Megamall as a landmark and their reference point. The square functions as a recreation area and gathering area for local people or local visitors who know about the existence of this square. This enhance the previous study conducted by Ismail and Nor Zalina (2009), who found that the morphological changes in Padang Pahlawan result its loss of character and the weakening of place identity.

\section{Imageability of Banda Hilir}

Substantially, 35 respondents participated willingly in the mental mapping conducted by the researcher as it was the survey method fundamental to research which consisted of nineteen (19) men and sixteen (16) women. Both local and foreign tourists are with the age range between sixteen (16) to sixty five (65) years old, inclusive of twenty (20) local visitors, and the remaining fifteen (15) were foreign visitors. There are three types of engagements of the participants. Ten (10) of the respondents came to Banda Hilir for the first time, whereas another fourteen (14) were tourists who had visited Banda Hilir more than once. In addition, the remaining eleven (11) were frequent visitors. Their diversity of working backgrounds dispersed widely from government servant, driver, teacher, engineer, student to pensioner as well as two (2) unemployed and one (1) full time housewife.

Based on the pilot study, the centre of the historic district of Banda Hilir, Melaka appeals to numerous visitors to amass there bringing along their families and friends. Hence interviews among the chosen visitors within the visitable zone and mostly occurred at public places namely, seating areas, eating spots, waiting areas and open spaces or areas conducive for passive activities and relaxations.

The attributes and objects are manifested in our experience of places that governs our impression of the uniqueness and identity of these places (Norsidah, 2010). Evidently, the identifications of landmarks in Banda Hilir, Melaka from the visitors' mental perception are amply evaluated in this section. All of the respondents were able to identify and signify elements or features that they perceived as landmarks. Apparently, four types of maps can be produced from a mental mapping exercise as previously classified by Shuhana et. al (2002) which are full map, segmented map, sequential map and skeletal or simple map. In contrast, as revealed by this study, majority of the respondents drew simple maps. Only five (5) of the respondents attempted to outline a segmented map while another two (2) formed a sequential map. However, those participants' inconclusive drawings were not feasible to be categorized under these two categories due to the insufficient and obscure data in the maps. Displayed below are examples of the map of landmarks produced by the respondents. 


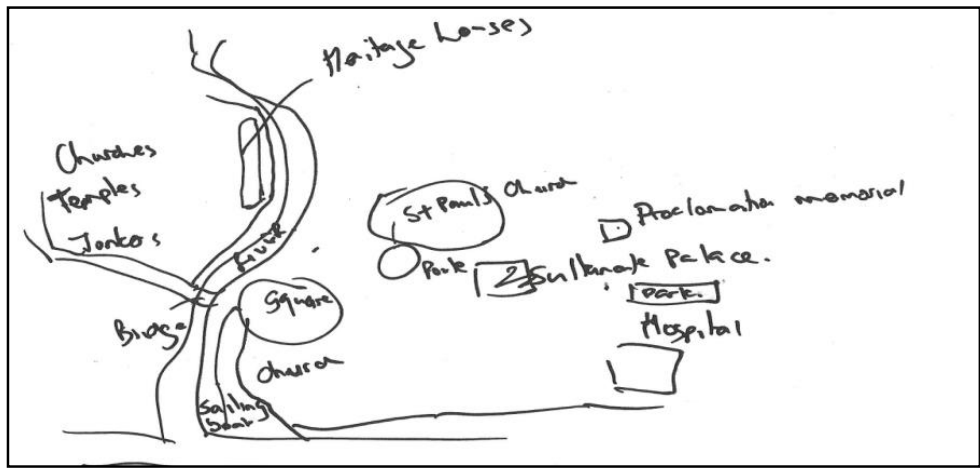

Figure 2. Simple map of landmark sketched by R6 (Source: Mental Mapping, 2012)
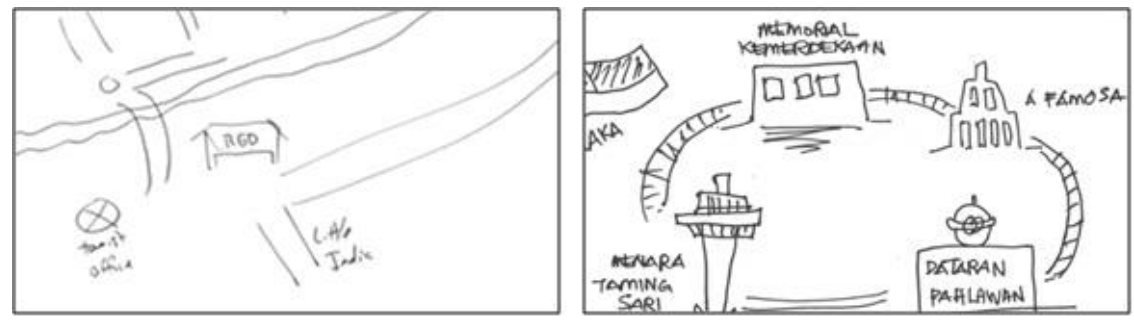

Figure 3. Identifications of landmarks illustrated by the visitors (R2 and R5), showing attempts to produce segmented (left) and sequential maps (right)

(Source: Mental Mapping, 2012)

The respondents identify landmark that include the old and new elements or features of Banda Hilir. The participants inclined to sketch maps by utilizing symbols or shapes in order to illustrate the recognizable landmarks. Likewise, the results signify the accumulation of 27 chief elements or features which classified by the respondents as landmarks. Table 1 below reveals the top ten (10) most identified landmark accordingly from the most to the least identified.

Table 1. Top 10 Most Identified Landmarks among Visitors in Banda Hilir, Melaka

\begin{tabular}{llll}
\hline No. & Landmarks & Frequency & Notes \\
\hline 1 & Melaka River & 17 & Other landmarks that are being \\
2 & St. Paul Church & 15 & identified with a smaller \\
3 & Jonker Street & 10 & frequency: \\
4 & Christ Church & 10 & - St. Paul Hill \\
5 & MuziumSamudera & 9 & - BalaiSeniLukis \\
6 & Menara Taming Sari & 9 & - Little India \\
7 & Red Square & 8 &
\end{tabular}




$\begin{array}{lll}8 & \text { Porta De Santiago/ A. Famosa } & 6 \\ 9 & \text { Water Fountain at Red Square } & 4 \\ 10 & \text { Mahkota Parade and } & 3 \\ & \text { DataranPahlawan Melaka Megamall } & \end{array}$

- Hardrock Café

- Tower Clock at Red Square

- Bangunan Memorial Kemerdekaan

- Bangunan Istana KesultananMelayu Melaka

- Stadhuys

- The waterwheel replica

- Dutch Graveyard

- Museums

- Shoplots in front of the Melaka River

- Hotels

- Taman Merdeka

After further analysis of the mental maps, the logical deduction implies over the respondents' tendency to specify landmarks within in the historical site which is the centre of attraction for Banda Hilir, although the study area encompasses the entire vicinity of Banda Hilir. Thus, it is evident that this visitable zone is far more substantial and more captivating for them to relate it with their mental images. However, need to bear in mind that, in the first stage of mental mapping, familiarity is not being examined as the initial intention is just to identify landmarks that creates image of the city among the visitors.

In this study, the identification might occur from the experience of visitors with the landmarks. Meanwhile, familiarity might be obtained accordingly through the period of involvement with the landmarks or with the influence of the landmarks' attributes. Visitors' identification later indicates their signs of familiarity towards the landmarks where the respondents associates their attraction with the attributes of the landmarks influence their identifications. This was reflected in the second stage of mental mapping where they were asked to draw the most familiar landmark, as stated by Lynch (1960), landmarks are "the most used clues of identity and even of a structure" which increase familiarity of an individual. Human experience and behaviour are developed through a network of memories and identities attached to the environment (Cheshmehzangi and Heath, 2012).

Astonishingly, it is apparent from Table 1 that the most identifiable landmark highlighted by the majority of the respondents is the Melaka River. This finding was quite unexpected probably because of two main reasons. Firstly, the participants unintentionally sketched the river as part of their illustrations as an edge. Secondly the river actually imparted a primary visual as a landmark in the visitors' cognition. Similarly, antecedent research utilizing mental mapping conducted by Shuhana et.al. (2002) had reported that the Melaka River was initially drawn by 60 percent of their respondents as the most identifiable advantage in this city. This has led to a conclusion that the river is substantial in creating the basic structure of the city in the mind of the participants. However, based on further explanation of their drawings, some of the respondents perceived this river as a landmark in particular therefore such identification verified the element as a landmark. Furthermore, based on the researcher's 
observation, the attribute of the river is contrastingly diverse with the surroundings furthermore it is clearly visible from a distance. As supplementary, this result supports earlier finding from Hasanudin (2003) who categorized natural elements and defined features, elements or spaces that are influential and distinguishable from its surrounding as a landmark.

Subsequently, among the visitors in Banda Hilir, Christ Church was placed in the fourth position of the most identified landmarks. Although Christ Church partially constitutes the Red Square in Banda Hilir, it garners special recognition from the visitors' identification. Likewise, the study portrayed identical outcomes in the adjacent stage of mental mapping, where the respondents could illustrate a $2 \mathrm{D}$ or $3 \mathrm{D}$ sketch of the most recognizable elements or features which they regarded as landmarks. They also need to state or justify the landmarks' characteristics and attributes that they found most appealing whether via drawing or writing. Hence, in the succeeding section, the results on landmarks' characteristics and attributes will also be discussed. Table 2 signifies the results of the most familiar landmarks to the visitors.

Table 2: The Most Familiar Landmarks Identified by Visitors in Banda Hilir, Melaka

\begin{tabular}{|c|c|c|c|}
\hline No. & Landmarks & Frequency & Notes \\
\hline 1. & MuziumSamudera & 8 & \multirow{6}{*}{$\begin{array}{l}\text { Other landmarks identified (with a smaller frequency) } \\
\text { - Kota Melaka } \\
\text { - Muzium Istana KesultananMelayu Melaka } \\
\text { - The waterwheel replica } \\
\text { - Jonker Street } \\
\text { - BalaiSeniLukis, } \\
\text { - Water Fountain at the Red Square } \\
\text { - DataranPahlawan Melaka Megamall }\end{array}$} \\
\hline 2. & Menara Taming Sari & 6 & \\
\hline 3. & St. Paul Church & 4 & \\
\hline 4. & $\begin{array}{l}\text { A. Famosa (Porta de } \\
\text { Santiago) }\end{array}$ & 3 & \\
\hline 5. & Christ Church & 3 & \\
\hline 6. & Mahkota Parade & 2 & \\
\hline
\end{tabular}

Source: Mental Mapping (2012)

Surprisingly, the landmarks that surpassed one of the most established and renowned historical icons and symbols of Melaka, the Porta De Santiago or A. Famosa ranked lower than the Muzium Samudera and Menara Taming Sari. Both ranked at number five (5) and six (6) as noted in Table 1 and number one (1) and two (2)as shown in Table 2. However, A. Famosa stationed at number seven in the rank in Table 1 and number four in Table 2, despite being one of the least identified landmarks. Based on the observation, the plausible cause might possibly due to the scale and size of Muzium Samudera and Menara Taming Sari which are tremendously larger than A. Famosa. Of such, this corroborates the constant debate that the new buildings have diluted the dominance and superiority of the aged structures which have distracted the visitors' fascination and captivation.

Once again, for St. Paul Church merely four (4) respondents identified the building as the most familiar landmark although fifteen (15) people actually acknowledged the church in their maps (see Table 1). This has decreased the impact of historical landmarks towards the city's identity. From the observation as can be viewed in Figure 4 below, the developments 
affect place identity of Banda Hilir's core zone. The new expansion and advancement in the buffer zone inclusive of Mahkota Parade, Dataran Pahlawan Melaka Megamall, Casa del Rio areas and the Immigration, Customs, Quarantine and Security Complex Melaka and hotels areas.

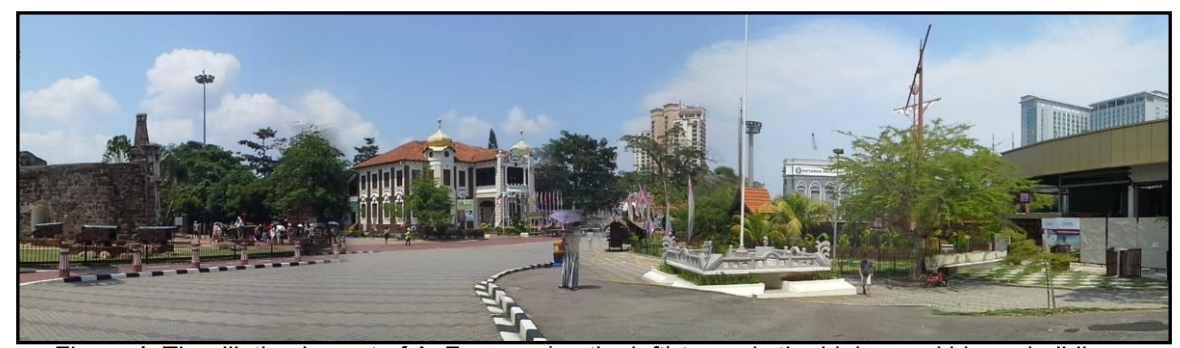

Figure 4. The dilution impact of A. Famosa (on the left) towards the higher and bigger buildings

(DataranPahlawan Melaka Megamall, Equatorial Hotel and Hatten Hotel) and structures within its vicinity

Hence, an inference could be deduced from this study is that a landmark will incessantly be identified by the visitors indicating the role of landmark in forming and forging the city image and identity thus supporting attachment to the city as a tourist destination. It is arguable that the historical identity of the city is weakening due to the construction of new buildings. This study derives that the strength and potency of the identity of Banda Hilir is alarmingly facing gradual reduction and decrement. The debatable factor matches the numbers of identification of landmarks procured from the respondents regarding the new structures which are higher or equally matched with the existing historical landmarks. These recorded outcomes might as well designate the prior inference on visitors' imageability since their mental images are depicting the place identity.

From the acute observation undertaken in the survey, several visitors identified landmarks according to their preferences and the significance of the landmarks. Different perceptions emerged probably due to the association with the attributes of the landmarks that fascinated them (Hasanudin, 2003). The sense of place is developed not only through the ability of the physical elements to stimulate the human senses but also the form and degree of attachment as a result of a strong identification of urban elements and continuous engagement in activities (Norsidah and Shuhana, 2012).

\section{Attributes and Characteristics of Landmarks}

From antecedent researches, the illustrations generated throughout the mapping exercises are affiliated with the attributes of landmarks. Thus, the attributes impacted their imageability towards the city. The chief attributes as categorized by Hasanudin (2003) are inclusive of scale, proportion and size, colours, singularity, location/ strategic position, ornamentation/ detail richness/ decoration, orientation/ wayfinding/ point of reference, symbolism and design style/ architectural value. To supplement, the landmarks illustrated by the respondents might be characterized by one or more of these attributes.

In the mental mapping exercise, the researcher asked the respondents to produce two or three dimensional $(2 \mathrm{D}$ or $3 \mathrm{D})$ drawings of the most familiar landmarks to the participants 
based on their own sketching maps. During the process, the respondents had the tendency to use their own words to describe the unique properties of landmarks like 'style', 'the old brick' instead of 'façade' as normally used in the architectural terminology.

For example, R20 had verified from her mental mapping on her appreciation and attraction towards the momentous size and scale, symbolism and the singularity of the Muzium Samudera. In the meantime, R5 expressed his attention on the utilization of architectural and design styles and materials as visualized in detail or richness of the façade of A. Famosa (Porta De Santiago). To add, R20 explained that the dominant size of the Muzium Samudera assisted in her way finding and orientation within the city. These intricacies can be clearly viewed from their illustrations of the most recognizable landmarks shown in Figure 5 below:
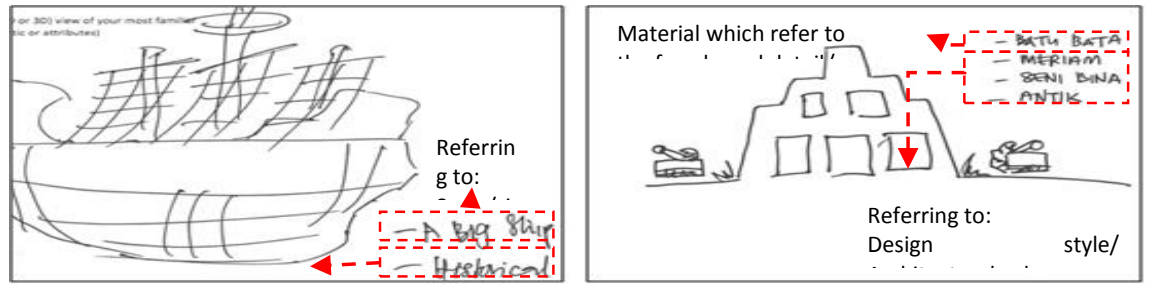

Figure 5. Sample of sketchingand notes on the characteristics of the most familiar landmarks in Banda Hilir
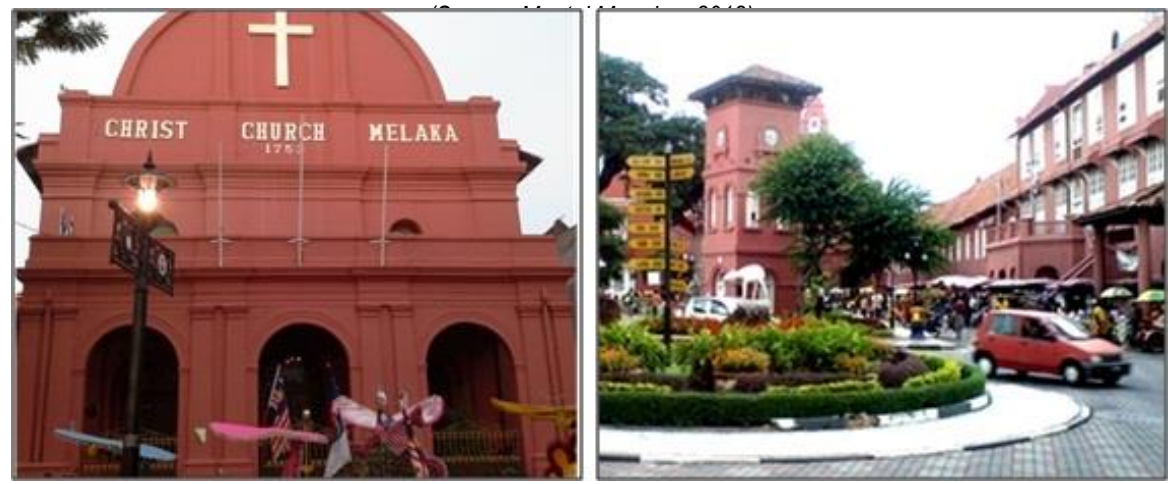

Figure 6. The Christ Church (left) and the red building (right) were incessantly referred to as landmarks due to its striking colour with distinctive architectural design.

From the mental mapping data, another glaring attributes mentioned mostly by the respondents when they described the sketches was the colour of the Red Square's buildings which include the Stadhuys, Christ Church and Balai Seni Lukis. Further validation from the observation highlights that the distinctive characteristic since the striking colour has the potency to attract and capture the visitors' attention and interest from a fair distance (see Figure 6). Similarly as shown in Table 1, based on the researcher's analysis of the drawings, 
Christ Church building has captured more attention probably due to its prominent Dutch's architectural design and distinctive colour.

Referring to the phenomenon in the identification of landmarks (as noted in Table 1 and Table 2), the newly built structures overgrow the identification of historical landmark. The steadfast observation confirmed that the scale and size of the newly built landmarks attract more attention and interests as well as visually shaped and forged the city in the mental images of visitors. However, the identification of historical landmark and its characteristics indicate the impact of the elements to the visitors' experience of the place. The undeniable attraction towards the new commercial buildings has not influenced the scenario. Banda Hilir has been regarded as a district with a strong heritage values. However the area faces the threat from the new and dominant structures which are not in harmony with the historical identity of the place.

\subsection{Conclusion}

The study confers that the recently constructed landmarks diminished the identity of the place and diluting the attraction of the historical landmarks. Nevertheless, most of the visitors have regarded old structures and elements as landmarks. However the identification on newly built landmarks, although not as strong, gives an indication of the increasing dilution of the historical landmarks that define the image of the city. Thence the findings of the study signify the visitors' imageability since it is depicting the identity of the city as a historical place of attraction. In this case, future development should integrate elements and features that could match and be more sympathetic to the initial identity of the city as a world heritage site. This study establishes the importance of place imageability and identity to be considered in enhancing the new or future development within a historic city. This can make the city more meaningful and memorable for the visitors.

\section{Acknowledgement}

This paper presents part of the findings from a research work funded by the Ministry of Higher Education of Malaysia on "The Effect of Historical Landmark on People's Attachment to the Historic District of Banda Hilir Melaka". The authors also acknowledge the Universiti Putra Malaysia for facilitating the research.

\section{References}

Hasanudin, L. (2003). A Comparative Analysis of Perception of Urban Landmarks Between Designers, Nondesigners and Laypublic : Kuala Lumpur Malaysia. Unpublished PHD Thesis, University of Sheffield.

Ismail, S., \& Nor Zalina, H. (2009). The Morphological Transformation of Public Place in Historic Town. Department of Landscape Architecture, Universiti Teknologi Malaysia, 0-3.

Kevin Lynch. (1960). The Image of The City. Mass: MIT Press. 
Lai, L. Y., Said, I., \& Kubota, A. (2013). The Roles of Cultural Spaces in Malaysia's Historic Towns: The Case of Kuala Dungun and Taiping. Procedia-Social and Behavioral Sciences, 85, 602-625.

Norsidah, U. and Shuhana, S. (2012). The influence of legibility on attachment towards the Shopping Streets of Kuala Lumpur. Pertanika. Vol. 20 (1). 81-92.

Shuhana, S. et al. (2002). Developing a Guideline for Designing Urban Intervention in Places of Historical and Cultural Significance in Malaysia.

Sulsters, W.A. (2005). Mental mapping, Viewing the Urban Landscapes of the Mind. International Conference "Doing, Thinking, Feeling Home: The Mental Geography of Residential Environment", at the OTB in the City of Delft, Netherlands, 14-15 October 2005. 